\author{
Kelvin W. Willoughby \\ WHAT IMPACT DOES INTELLECTUAL PROPERTY \\ HAVE ON THE BUSINESS PERFORMANCE OF \\ TECHNOLOGY FIRMS? \\ International Journal of Intellectual Property Management \\ Vol. 6, No. 4 (2013), pages 316-338. \\ DOI: $10.1504 /$ IJIPM.2013.057634 \\ (C) 2013 Inderscience Enterprises Ltd.
}

This is a pre-publication draft only.

For access to the final published version please go to the publisher's web site at:

http://www.inderscience.com

For a direct link at the publisher's web site to the article go to:

http://www.inderscience.com/dev/search/index.php?mainAction=search\&action=record\&rec i $\mathrm{d}=57634 \&$ prevQuery $=\& \mathrm{ps}=10 \& \mathrm{~m}=$ or 
K.W. Willoughby 


\title{
What impact does intellectual property have on the business performance of technology firms?
}

\author{
Kelvin W. Willoughby \\ School of Electrical Engineering and Computing \\ Faculty of Science and Engineering, Curtin University \\ GPO Box U1987, Perth WA 6845 Australia \\ Email: k.willoughby@curtin.edu.au \\ Web: www.DrKelvinWilloughby.com
}

\begin{abstract}
This paper reports the results of an original empirical study of the relationship between intellectual property and the financial performance of technology firms in the bioscience-technology industries. The study found a statistically significant positive relationship between the firms' investments in intellectual property and their performance. The performance measure was based upon revenue-growth data collected from each firm, and the categories of intellectual property analyzed included patents, trade secrets, trademarks, copyright and licenses to externally sourced technology. The study also found that the financial benefits of accumulating a strong intellectual property portfolio were enjoyed by technology firms regardless of whether they were strategically oriented towards $\mathrm{R} \& \mathrm{D}$ or strategically oriented towards the commercial production of products and services.
\end{abstract}

Keywords: Intellectual property; patents; trade secrets; trademarks; copyright; licenses; financial performance; R\&D; production; strategic management of IP

Reference to this paper should be made as follows: Willoughby, K.W. (2013) 'What impact does intellectual property have on the business performance of technology firms?', Int. J. Intellectual Property Management, Vol. 6, No. 4, pp.316-338.

Biographical notes: Kelvin Willoughby is Professor of Entrepreneurship and Intellectual Property in Curtin University's Faculty of Science and Engineering. His research and teaching concentrate on the management of intellectual property, technology-based entrepreneurship, and strategic planning for technology-based industry development. He holds doctorates in both strategic management and technology studies, and a master of laws degree in intellectual property law. Professor Willoughby has extensive experience as an educator, researcher, consultant and program leader in the United States, Europe, Asia and Australia, including a variety of university-industry collaboration projects, technology commercialization projects and executive education projects.

\section{Introduction}

The main goal of this paper is to investigate whether the accumulation of intellectual property by technology firms has a significant impact on their business performance. Additionally, the paper seeks to identify whether the strategic orientation of a technology firm - specifically, the intensity of its engagement in either research and development or 


\section{K.W. Willoughby}

the production of goods or services - makes any difference to the level and character of the impact of intellectual property on its business performance.

\section{Context: The Strategic Management of Intellectual Property}

While intellectual property may once have been perceived as the peculiar preserve of eccentric lawyers, as a diversion for obsessive boffins, or as a "necessary evil" (to be shunted off in to the backrooms of corporate legal departments), it has become part of the mainstream of contemporary business. Intellectual property is now widely recognized as being strategically important for companies across a wide variety of industries, ranging from research-intensive high technology enterprises to multi-national media and publishing groups, not to mention firms engaged in "primary" industries such as farming, mineral exploration or mining. Accordingly, a sizable body of scholarly research has appeared during the last decade concerned with the practical role of intellectual property in business. Examples include: Blind, et al. (2009); Cohen, et al. (2002); Elmslie and Portman (2006); Fitzpatrick and DeLullo (2005); Lehman (1996); Lichtenthaler (2009); Parchomovsky and Wagner (2005); Peeters and van Pottelsberghe de la Potterie (2006); Pisano and Teece (2007); Rherrad and Gallaud (2009); Rose, et al. (2007); Roy (2013); Solitander and Solitander (2010); Walden (2005); Willoughby (2013).

Recently, the strategic management of intellectual property has become visible in mainstream research in the academic field of strategic management, where it is typically portrayed as a source of competitive advantage for firms or as a "resource" to be managed strategically along with conventional business resources [see, e.g.: Arora and Nandkumar (2012); Hsu and Zeidonis (2013); Lichtenthaler and Ernst (2012); Mulotte, et al. (2013); Pacheco-de-Almeida and Zemsky (2012); Valentini (2012)]. The contemporary strategy literature addresses multiple types of intellectual propertypatents, copyright, trade secrets, licenses, etc.-and not just patents. Increasingly [e.g., Hsu and Zeidonis (2013)], attention is being placed, not only on the role of intellectual property within the repertoire of activities and functions of the firm, but also on the impact of intellectual property on the performance of the firm, broadly understood. As part of this trend it may be said that the academic study of intellectual property management has shifted during the last decade from being perceived by management scholars as little more than a peripheral and heterodox pursuit to finding a place within the academy's outer chambers of orthodoxy.

\section{Intellectual Property, Innovation and Business Success}

A substantial focus of attention in the literature on the strategic management of intellectual property lies with the relationship between intellectual property ("IP") and innovation, particularly technological innovation [see, e.g.: Blind, et al. (2006); Cincera (1997); Cohen, et al. (2000); Graham, et al. (2009); Greenhalgh, et al. (1996); Hsu and Ziedonis (2013); Lynskey (2009)]. A line of inquiry within that literature views intellectual property as a plausible determinant of the business performance of firms. In some cases, however, there is little differentiation in the minds of researchers and commentators between the concepts of "business performance" and "innovation," as such, with intellectual property often being treated as an indicator of innovative 
performance by firms, rather than as a determinant of the innovative performance of firms. Nevertheless, "business performance" and "innovation" are discrete concepts; and the literature concerned with the financial dimensions of the performance of innovative IP-intensive firms now appears, on the whole, to have embraced, at least tacitly, the conceptual distinctions between innovation potency, IP potency and business potency.

Some of that literature approaches financial performance from the vantage point of the firm's ability to attract capital or increase the value of its capital stock through the strength of its intellectual property [see, e.g.: Bosworth and Rogers (2001); Bessler and Bittelmeyer (2008); Cockburn and Griliches (1988); Hsu and Ziedonis (2013); Mann and Sager (2007); Willoughby (2008)] and the general conclusion of that literature is that, in the main, intellectual property makes a positive difference to a firm's ability to attract outside investment. While the literature has not yet reached consensus on the question of whether the capital-raising benefits of intellectual property accrue to small entrepreneurial firms as much as they do to large mature firms [see, e.g., Bessen (2008); Willoughby (2008)], the general conclusion of the literature is that there is a positive relationship between a firm's intellectual repertoire - especially its patent portfolio — and its ability to raise capital, regardless of the size of the firm. The following quote from Mann and Sager (2007, p. 206), based on their own empirical research on the place of intellectual property in venture capital financing for software firms, represents the signal theme in the literature:

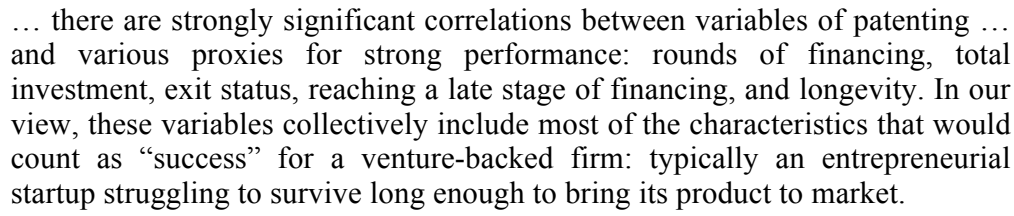

While success in raising capital as a consequence of a firm's intellectual property position may certainly be considered as one expression of business success, the focus of attention of the research reported in this paper is on the "output" side of financial performance rather than the "input" side. In other words, we are interested here in the difference that intellectual property makes to the relative performance of firms in generating financial returns through the sale or rent of products, services or assets, rather than in the difference that it makes to their success in attracting financial investment.

\section{Intellectual Property and the Financial Performance of Firms}

A number of published studies, covering a broad variety of geographical settings and industries, have addressed this topic in recent years. The majority of those studies appear to have identified a positive relationship between a firm's investment in intellectual property and its business performance, and its financial performance in particular. Representative examples include: Anuar, et al. (2012), wide variety of manufacturing industries in Malaysia; Bollen, et al. (2005), pharmaceuticals industry in Germany; Bosworth and Rogers (2001), wide variety of large, publicly traded firms in Australia; Cohen and Kaimenakis (2007), service-sector firms in Greece; Graham and Sichelman (2008), literature survey and wide variety of technology start-up firms in the United States; Greenhalgh and Longland (2005), Greenhalgh and Rogers (2006 \& 2007), wide 


\section{K.W. Willoughby}

variety of manufacturing firms in the United Kingdom; Hanel (2008), manufacturing firms from many industries in Canada; Hsu and Ziedonis (2013), semiconductor firms in the United States; Juma and McGee (2006), technology firms from eleven different industries in the United States; Lichtenthaler (2009), European-wide study, many industries; Namvar, et al. (2010), electronics and computing firms in Iran; Pandit, et al. (2011), multi-national study, broad variety of technology-intensive industries and sectors; Roy (2013), information technology firms in India; and, Suh and Hwang (2010), computer software firms in South Korea.

The above studies, when taken together as a set, reveal that the exact character of the relationship between intellectual property and business performance varies considerably between geographical contexts, industries and environmental conditions. Some studies [e.g., Suh and Hwang (2010), Greenhalgh and Rogers (2007) or Rherrad and Gallaud (2009)] have stressed that the relationship also varies according to which type of intellectual property right is covered in the analysis. Suh and Hwang (2010), for example, have argued that copyright is more important than patents for software firms, whereas patents are more important than copyright for manufacturing firms. Greenhalgh and Rogers (2006), furthermore, have observed that, in the case of patents held by manufacturing firms, the array of countries from which patents are issued appears to have a stronger influence on the relationship between patenting and business performance than does the simple fact of patenting. European patents issued to UK firms, for example, appear to have a statistically significant positive relationship with improved business performance by UK firms; whereas UK patents issued to UK firms appear, in general, to have no significant impact on the business performance of UK firms [Greenhalgh and Rogers (2006)].

However, despite the general consensus among researchers that we have just summarized, the story from the literature is not so simple or uniform. Martin and Mykytyn (2009) have found no observable impact on the business performance of firms of patenting computer-implemented business methods. From their study of 96 US firms (48 of which did own patents and 48 equivalent firms which did not own patents) they concluded the following:

The overall results revealed that our sample of patenting firms did not perform significantly differently from their nearest competitors or their relative industries in five profit or three cost measures.

Mahlich (2010), furthermore, in his study of the pharmaceutical industry in Japan, has concluded that patenting is negatively related to the business performance of pharmaceutical firms. His measure of relative business performance in that study was profitability. A similar conclusion was reached by Artz, et al. (2010) in their study of a sample of 272 firms in the United States in 35 industries over 19 years. They discovered a negative relationship between the level of patenting and both return-on-assets and sales growth for the firms. Thus, while the preponderance of pertinent studies published in the literature point to a positive relationship between the size of the intellectual property portfolio of firms and their financial performance, the relationship is not straightforward; and there are some studies published in the literature that have found the opposite to be the case (i.e., they point to a negative relationship between the size of the intellectual property portfolio of firms and their financial performance). Further research on the core question of this paper is therefore warranted. 
What impact does IP have on the business performance of technology firms?

\section{Hypotheses for Empirical Research}

The first hypothesis that flows from the literature just surveyed is therefore as follows:

Hypothesis 1: The accumulation of intellectual property by technology firms has a positive impact on their financial performance.

Hypothesis 1, in other words, is designed to test whether there is a positive relationship between the relative levels of intellectual property held by firms and their relative financial performance.

Much of the literature concerned with the relationship between intellectual property and business performance is focused on $\mathrm{R} \& \mathrm{D}$-intensive firms, or $\mathrm{R} \& \mathrm{D}$-intensive industries, and there appears to be a general presumption that obtaining and managing intellectual property is most relevant to firms that engage heavily in research and development [see, e.g., Bosworth and Rogers (2001); Cincera (1997); Cockburn and Griliches (1988); Greenhalgh and Rogers (2006); Griliches (1981)]. This raises the question of whether or not the potential business benefits of building a strong intellectual property profile might be enjoyed more readily by firms that are relatively strong in research and development. A number of studies have provided evidence that this might be so. Examples include: Blind, et al. (2006); Bosworth and Rogers (2001); Cockburn, et al. (2010); Lichtenthaler (2009); Rherrad and Gallaud, (2009); Pandit, et al. (2011); and, Suh and Hwang (2010).

However, there is also some evidence in the literature that the financial benefits to firms of investing in intellectual property accrue more readily to those that engage heavily in manufacturing, or production, activities [Cohen, et al. (2000); Greenhalgh, Mavrotas and Wilson (1996); Greenhalgh and Rogers (2006)]. Thus, we have contrasting, although not necessarily contradictory, messages emerging from the literature about whether or not R\&D-intensive firms or production-intensive firms are best positioned to take advantage of strong intellectual property portfolios. Notwithstanding the fact that the dominant presumption in the literature appears to be that intellectual property is more useful to R\&D-intensive firms than it is to other types of firms, it would be prudent to investigate this matter in more detail.

Thus, two more hypotheses are suggested by the literature:

Hypothesis 2: Insofar as the accumulation of intellectual property by technology firms has a positive impact on their financial performance, the degree of this positive impact will be positively related to the degree to which the firms concentrate their efforts on research and development activities.

Hypothesis 3: Insofar as the accumulation of intellectual property by technology firms has a positive impact on their financial performance, the degree of this positive impact will be positively related to the degree to which the firms concentrate their efforts on the commercial production of goods or services.

Hypotheses 2 and 3 are complementary and are designed, together, to test the relative importance of R\&D-intensity and production-intensity as factors moderating the relationship between intellectual property and the financial performance of firms. In simultaneously proposing these two hypotheses, we are assuming that it is not impossible for a firm to be R\&D-intensive and production-intensive at the same time. We will 


\section{K.W. Willoughby}

elaborate on this assumption below, during our discussion of the empirical results of this study. In effect, we are presuming that production-intensity and R\&D-intensity should be treated as discrete and orthogonal variables, rather than as different phases along the spectrum of a single variable with "pure R\&D" at one end and "pure production" at the other end.

\section{Data Source for the Empirical Research}

All of the data utilized for the analyses reported in this paper came from an original empirical study, conducted by the present author, of technology firms in the biosciencetechnology industries in the United States. The bioscience-technology industriessometimes also referred to as the "life sciences," "bioscience" or "bio" industriesconsist of biotechnology firms, medical devices firms, pharmaceuticals firms, and firms in various other fields of technology related to the life sciences, such as bio-processing or bio-materials. This group of firms may be labeled collectively as the "biosciencetechnology" sector.

The data were generated by administering a detailed structured questionnaire survey to the CEOs of a sample of 184 bioscience-technology firms in the United States during 1997 and 1998. The work involved three phases: (i) sending introductory letters to the CEO of each firm to introduce the study and its purposes; (ii) completing the first half of the questionnaire through a structured telephone interview with the CEO (or CEOequivalent) of each firm; and, (iii) completing the balance of the questionnaire by obtaining completed responses by fax or mail to a set of printed interview sheets. Data were provided by each of the firms under a promise of confidentiality. Each of the 184 firms included in the sample for this project were bona fide technology companies in which technology formed a major and integral part of their business. ${ }^{1}$

The basic morphology of the firms in the study sample is as follows. The average size of the firms was 146 employees, although about $60 \%$ of the firms employed no more than 25 people, and only about $11 \%$ employed 300 or more people. The average age of firms in the sample was just over sixteen years; although at the time of the data collection $47 \%$ of the firms had been in existence for no longer than ten years and a full $24 \%$ had been in existence for no longer than five years. Eighteen percent were over 25 years old. Over $65 \%$ of the firms in the sample were either small (no larger than 25 people) or young (no older than 5 years). Almost one fifth of firms in the sample (17.5\%) were classic "startup" firms (no larger than 25 people and no older than 5 years). Despite the fact that the majority of the firms in the sample were relatively small, young and entrepreneurial, the average annual revenue per firm in the data set was over US\$35 million.

The vast majority of firms in the sample (79\%) were privately held (i.e., their stocks were not publicly traded), and $85 \%$ were freestanding, independent firms (i.e., they were not a subsidiary of some other company). It may therefore be inferred that the majority of firms were organizationally free to make strategic decisions. The single largest industry focus of the firms in the data set was medical devices technology (52\% of the sample), with $39 \%$ focused on biotechnology, $25 \%$ on pharmaceuticals, and $17 \%$ on bio-systems.

\footnotetext{
${ }^{1}$ Note: The data set upon which this study is based was also the basis for another study published by the current author [see Willoughby (2013)].
} 
The four industry categories are not discrete, which means that a firm may have been simultaneously active in more than one industry category. In fact, almost one third of the 184 firms in the study sample were simultaneously active in more than one industry.

\section{Variables and Models Included in the Analysis}

In addition to basic information about their technological, organizational and business profiles, each firm included in the study was asked to provide confidential information about the number of intellectual property items of various types that it owned, including: patents, formal trade secrets, trademarks, copyright protected items (mostly computer software applications), and licenses to technology owned by external parties. Information was also collected about total world-wide full-time-equivalent employment of people in each firm, together with estimates of the functional distribution of employment across the categories of: management and marketing, research and development, production, and other. Additionally, an array of financial data was collected for each firm, including annual revenue growth rates. These data were used to generate the numbers for the variables summarized in Table 1.

Table 1 Description of Variables

\begin{tabular}{|c|c|c|}
\hline Variable & Label & Definition / Description of Variable \\
\hline Total IP items & TIP & $\begin{array}{l}\text { Total number of Intellectual Property items held by the firm. } \\
\text { TIP }=\text { PT }+ \text { TS }+ \text { TM }+ \text { CR + LI }\end{array}$ \\
\hline Patents & PT & Total number of patents possessed by the firm \\
\hline Trade secrets & TS & Total number of formal trade secrets possessed by the firm \\
\hline Trademarks & TM & Total number of trademarks owned and used by the firm \\
\hline $\begin{array}{l}\text { Copyright-protected } \\
\text { items }\end{array}$ & $\mathbf{C R}$ & $\begin{array}{l}\text { Total number of works owned by the firm (mostly computer } \\
\text { software applications) that are protected by copyright }\end{array}$ \\
\hline Licenses & LI & $\begin{array}{l}\text { Total number of licenses held by the firm over technology } \\
\text { owned by external parties }\end{array}$ \\
\hline $\mathrm{R} \& \mathrm{D}$ intensity & RDI & $\begin{array}{l}\text { Percentage of total annual work time (full-time-equivalent } \\
\text { employment) in the firm devoted to research and development }\end{array}$ \\
\hline Production intensity & PRI & $\begin{array}{l}\text { Percentage of total annual work time (full-time-equivalent } \\
\text { employment) in the firm devoted to production activities }\end{array}$ \\
\hline \multirow[t]{5}{*}{$\begin{array}{l}\text { Financial } \\
\text { Performance } \\
\text { Index }\end{array}$} & FPI & $\begin{array}{l}\text { Financial Performance Index = Logarithm of REVIND } \\
\text { (weighted index of annual rate of revenue growth) }\end{array}$ \\
\hline & REVIND & REVIND $=$ ANNREV (INDEMP / MEANEMP) \\
\hline & ANNREV & Annual rate of revenue growth of the individual firm \\
\hline & INDEMP & Worldwide full-time-equivalent employment levels of the individual firm \\
\hline & MEANEMP & Mean worldwide full-time-equivalent employment levels for the study sample \\
\hline
\end{tabular}




\section{K.W. Willoughby}

The construct used in this study as a measure of the business performance of individual firms is the Financial Performance Index (labeled "FPI"), which is a logarithm of a weighted revenue-growth index. The weighted revenue-growth index is based on the annual rate of revenue-growth of firms, adjusted to compensate for the fact that entrepreneurial start-ups tend to have extraordinarily high rates of revenue-growth until they mature. The exact formula for the Financial Performance Index is provided Table 1. The Financial Performance Index measure employed in this study was originally used successfully by Willoughby (2004) in his study of innovation strategies of high technology firms. The Financial Performance Index (FPI) has a number of distinct advantages over conventional financial performance measures, such as profitability, market value, or share-price trends. One advantage stems from the fact that the vast majority of bioscience-technology firms are privately held (i.e., not traded on the public markets) and hence that data on their traded share prices simply do not exist-by definition. Similarly, in most cases, data on profitability is almost impossible to assemble because (by definition) such data for privately owned firms is usually not publicly available, and because privately held firms generally do not wish to reveal how profitable or unprofitable they are.

Table 2 Description of Formal Models

\begin{tabular}{ll}
\hline Model & General Form of the Model \\
\hline \hline Model 1 & FPI $=b_{0}+b_{1} \mathbf{T I P}+$ error \\
Model 2 & FPI $=b_{0}+b_{1} \mathbf{P T}+$ error \\
Model 3 & FPI $=b_{0}+b_{1} \mathbf{T S}+$ error \\
Model 4 & FPI $=b_{0}+b_{1} \mathbf{T M}+$ error \\
Model 5 & FPI $=b_{0}+b_{1} \mathbf{P T}+b_{2} \mathbf{T S}+b_{3} \mathbf{T M}+$ error \\
Model 6 & FPI $=b_{0}+b_{1} \mathbf{P T}+b_{2} \mathbf{T S}+b_{3} \mathbf{T M}+b_{4} \mathbf{C R}+b_{5} \mathbf{L I}+$ error \\
Dependent Variable & FPI \\
\hline
\end{tabular}

Most of the managers interviewed as part of the data collection process in this study were willing to share information on the annual rate of revenue growth of their firm, under a promise of confidentiality, even if they were not willing to share data on profitability. Thus, a financial performance measure based on the collection of revenuegrowth data was much more feasible from the point of view of data collection than were other, perhaps more popular measures, such as market value or profitability.

Data on market value or profitability are generally only available for publicly traded firms (which in this study accounted for only about $20 \%$ of the firms in the study sample). Apart from these practical considerations, we need to bear in mind that the nature of the bio-science technology industries is such that "profitability" is arguably a 
poor measure of comparative performance due to the fact that even the best firms may take many years before their bottom line moves in to the black. The bottom lines of the "best" high technology firms are often deliberately kept in the red for many years after their foundation as part of the long-term development strategy of the entrepreneurs and investors who lead these firms. Hence, the Financial Performance Index employed in this study as a measure of the business performance of each firm is advantageous because of its robustness and rational applicability in the context of high technology industry, but also because of the natural feasibility and reliability of the data collection process: the pertinent data may be obtained relatively easily for all firms, no matter the stage of their development or whether or not their stocks are traded on the public markets.

Table 2 describes the formulae, containing the variables defined in Table 1, that were included in the models incorporated in the statistic calculations summarized below.

\section{Basic Results of the Statistical Analysis}

Table 3 consists of a correlation matrix that was produced for all of the variables. There do not appear to be any problems with multicollinearity. ${ }^{2}$ The correlation coefficients show that there is a relatively strong relationship between the financial performance of the firms in the study sample and the degree to which the firms include three particular types of intellectual property in their portfolios: patents, trade secrets and trademarks.

Table 3 Correlation Matrix of Variables

\begin{tabular}{|l|r|r|r|r|r|r|r|r|}
\hline & $\begin{array}{r}\text { Performance } \\
\text { Index }\end{array}$ & Patents & $\begin{array}{r}\text { Trade- } \\
\text { secrets }\end{array}$ & Trademarks & $\begin{array}{r}\text { Copyright- } \\
\text { protected } \\
\text { items }\end{array}$ & Licenses & $\begin{array}{r}\text { R\&D } \\
\text { intensity }\end{array}$ & $\begin{array}{r}\text { Production } \\
\text { intensity }\end{array}$ \\
\hline $\begin{array}{l}\text { Financial } \\
\text { Performance Index }\end{array}$ & 1.0000 & & & & & & & \\
\hline Patents & 0.4466 & 1.0000 & & & & & & \\
\hline Trade-secrets & 0.5372 & 0.4980 & 1.0000 & & & & & \\
\hline Trademarks & 0.4243 & 0.5037 & 0.4049 & 1.0000 & & & & \\
\hline $\begin{array}{l}\text { Copyright-protected } \\
\text { items }\end{array}$ & 0.0115 & 0.0254 & 0.0322 & 0.1288 & 1.0000 & & & \\
\hline Licenses & 0.0670 & 0.0957 & 0.0857 & 0.1468 & 0.3319 & 1.0000 & & \\
\hline R\&D intensity & -0.0696 & -0.0970 & -0.0345 & -0.2512 & -0.0669 & -0.0664 & 1.0000 & \\
\hline Production intensity & 0.0917 & 0.0201 & 0.0908 & 0.2447 & 0.0537 & 0.0721 & -0.6085 & 1.0000 \\
\hline
\end{tabular}

Note: The correlation coefficients in Table 3 were calculated using the Restricted Maximum Likelihood (REML) method.

Interestingly, neither the number of copyright-protected works owned by a firm (mostly copyright-protected computer software applications) nor the number of licenses to technology from external parties appear to have much bearing on financial performance. Likewise, the correlation coefficients reveal that variations in the degree to which firms emphasize research and development in their business, or the extent to which they are

2 According to Tabachnick and Fidell (1989, p. 87) multicollinearity is a problem when the predictors have correlation coefficients of 0.90 or greater. 


\section{K.W. Willoughby}

committed to production-intensive activities, appear to play no role in determining the relative financial performance of the firms. Presumably, this means that simplistic strategies for technology firms such as "increasing investment in R\&D" or "moving quickly to establish manufacturing operations" do not generally appear-at least by themselves - to produce superior business results. A core insight that may be drawn from the results in Table 3 is that, at least for the high technology industries represented in our data set, intellectual property appears to play a strategically potent role within the business of technology firms.

The correlation matrix in Table 3 also reveals that there is a relatively high correlation between the firms' reliance upon each of their three dominant types of intellectual property, namely, patents, trademarks and trade secrets. In other words, these three types of intellectual property not only feature prominently as drivers of firm performance but they tend to be employed concurrently. There is a correlation of approximately 0.5 between both the levels of patents and trademarks, on one hand, and the levels of patents and trade secrets, on the other hand, employed by the firms; and there is a correlation of approximately 0.4 between the levels of trademarks and trade secrets employed by the firms. In other words, it appears that the firms tend to rely heavily upon three (presumably complementary) types of intellectual property, rather than just one, such as patents. They emphasize a three-dimensional intellectual property portfolio approach rather than a one-dimensional approach to protecting their intellectual and technological assets.

The most important observation that may be gleaned from Table 3, in summary, is that variations in the financial performance of the firms appear to be related to variations in the degree to which they invest in intellectual property. This relationship will now be investigated in more detail.

\section{The Relative Impact of Different Types of Intellectual Property}

Table 4 displays the statistical results of the analysis of six different models of the relationship between the level of investment in intellectual property by firms and their business performance or, more particularly, their financial performance. The financial performance variable employed in all six models in the table is the Financial Performance Index (a weighted index of the annual rate of revenue growth) as defined in Table 1.

The results for Model 1 in Table 4 show that there is a statistically significant relationship between the financial performance of firms and the total number of intellectual property items that they possess, including patents, trade secrets, trademarks, copyright-protected works, and licenses to externally sourced technology, combined. Thus, Table 4 reveals that the basic conclusion that was gleaned from the results in Table 3 is statistically valid: there is a very low probability that the overall positive relationship between firms' strong IP portfolios and their strong financial performance may be explained by chance.

Model 6 in Table 4 isolates the contributions of each of the five different intellectual property variables in the data set, rather than aggregating them together as was done in Model 1. The results for Model 6 show that while the overall relationship between high levels of intellectual property and strong financial performance is clearly observable (with a probability of less than 0.005 that the relationship may be explained by chance), the effect of each individual variable is not well captured in that model. As foreshadowed 
What impact does IP have on the business performance of technology firms?

by the correlation coefficients in Table 3, no significant contribution may be observed from the results in Table 4 by either copyright or in-licensing of technology to the financial performance of firms. The results for Model 5 show that when copyrightprotected items and licenses are excluded from the calculations, the statistical significance of the overall relationship is markedly strengthened: when only patents, trade

Table 4 Intellectual Property and Financial Performance: All Firms

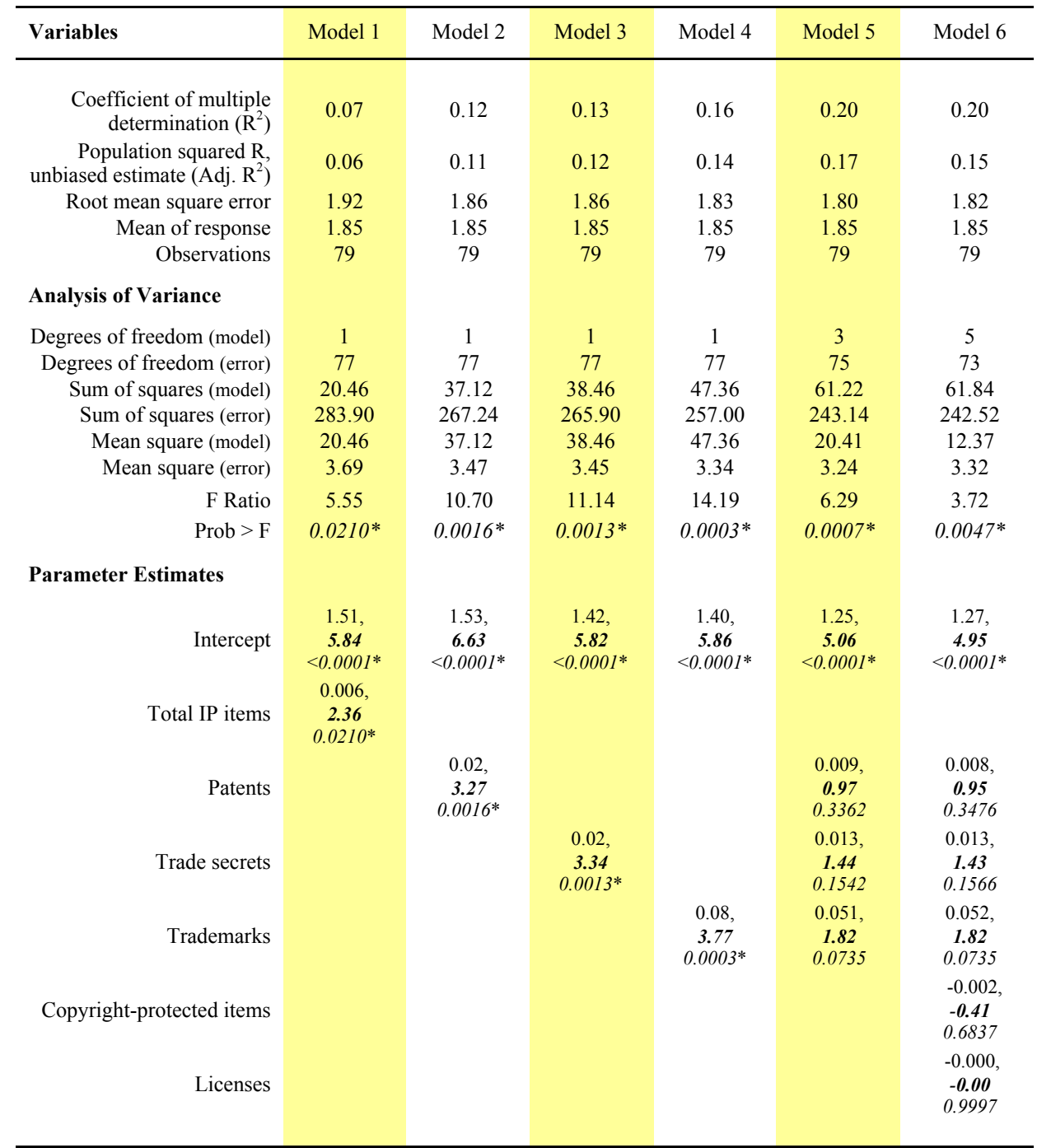

Key to Parameter Estimates: Coefficient of Correlation, $\boldsymbol{t}$ Ratio, Prob $>|t| \quad\left({ }^{*} \mathrm{P}<0.05=\right.$ significance level $)$

Dependent variable for all models $=$ Financial Performance Index

secrets and trademarks are included in the model the probability that the overall positive relationship between high levels of intellectual property and strong financial performance may be explained by chance is reduced to 0.0007 . Clearly, the important IP-related 


\section{K.W. Willoughby}

contributions to financial performance arise predominantly from the firms' investments in patents, trade secrets and trademarks, rather than from the other types of intellectual property.

Models 2, 3 and 4 in Table 4 are designed to examine the individual contributions to the financial performance of the firms of their investment in patents, trade secrets and trademarks, respectively. The main conclusion to be drawn from the results is that there is a statistically significant relationship for each of the three types of intellectual property in their own right. The probability that the positive relationship between the level of a particular type of intellectual property in the firm and the financial performance of the firm may be explained by chance is 0.0016 in the case of patents, 0.0013 in the case of trade secrets, and 0.0003 in the case of trademarks. In short, there is almost no chance at all that the relationship between a strong portfolio of patents, trade secrets and trademarks and strong financial performance is coincidental. Additionally, while it is evident that firms that invest in patents generally also invest in both trade secrets and trademarks, it appears that investment in each of these types of intellectual property contributes individually, in its own right, to the positive financial performance of the firms.

\section{The Moderating Role of Research and Development Activities}

We know from the results summarized in Table 3 that simply engaging more heavily in research and development activities does not, in itself, typically lead to an improvement in the financial performance of the firms. Nevertheless, it will be instructive to explore how investment in research and development might affect, or moderate, the relationship between a technology firm's investment in its intellectual property portfolio and its financial performance.

To explore this topic, Models 1, 2, 3, 4 and 5 were tested for two different groups of firms in the data set: one group designated as having "low R\&D intensity" and the other designated as having "high R\&D intensity." An estimate of the percentage of total work time devoted to R\&D by all employees combined, over a period of one year, was obtained for each firm. In other words, the proportion of annual full-time-equivalent employment devoted to R\&D functions was identified for each firm in the sample. The mean figure for all firms in the sample was then calculated and each firm was classified according to whether its proportion was higher or lower than the average. If the percentage of a firm's total annual work-time devoted to R\&D was less than average it was classified as exhibiting "low R\&D intensity" and, conversely, if the percentage of a firm's total annual work-time devoted to $R \& D$ was greater than average it was classified as exhibiting "high R\&D intensity." Separate regression calculations were then carried out for each of the two groups of firms for each of the five models. The results of this exercise are summarized in Table 5.

The results obtained for Model 1 in Table 5 show that the degree to which firms devote time to research and development activities does indeed make a difference to the overall impact on their financial performance of their investment in intellectual property. For the R\&D-intensive firms there is a strong, statistically significant, relationship between the total number of intellectual property items they possess and their financial performance. The probability that this relationship may be explained by chance is less than 0.006; whereas, for the firms with lower than average R\&D intensity, there is no statistically significant relationship between investment in intellectual property and 
What impact does IP have on the business performance of technology firms?

financial performance. The results obtained for Model 5 in Table 5-in which patents, trade secrets and trademarks are specified separately in the model-lead to the same overall conclusion: there is a positive and statistically significant relationship between overall investment in intellectual property and the financial performance of the R\&Dintensive firms; but such a relationship cannot generally be observed for firms with lower than average intensity of $R \& D$ activities.

Table 5 Intellectual Property and Financial Performance: Low vs. High R\&D Intensity

\begin{tabular}{|c|c|c|c|c|c|c|c|c|c|c|}
\hline \multirow[b]{2}{*}{ Variables } & \multicolumn{2}{|c|}{ Model 1} & \multicolumn{2}{|c|}{ Model 2} & \multicolumn{2}{|c|}{ Model 3} & \multicolumn{2}{|c|}{ Model 4} & \multicolumn{2}{|c|}{ Model 5} \\
\hline & 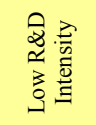 & 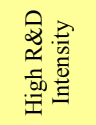 & 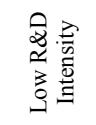 & 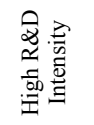 & 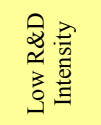 & 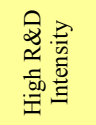 & 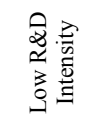 & 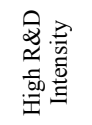 & 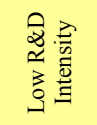 & 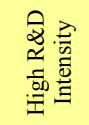 \\
\hline $\mathrm{R}^{2}$ & 0.02 & 0.24 & 0.08 & 0.25 & 0.11 & 0.19 & 0.07 & 0.35 & 0.13 & 0.40 \\
\hline Adj. $R^{2}$ & -0.004 & 0.21 & 0.06 & 0.22 & 0.09 & 0.16 & 0.05 & 0.33 & 0.07 & 0.33 \\
\hline RMS error & 1.93 & 1.78 & 1.87 & 1.77 & 1.84 & 1.84 & 1.88 & 1.64 & 1.86 & 1.64 \\
\hline Mean & 2.11 & 1.42 & 2.11 & 1.42 & 2.11 & 1.42 & 2.11 & 1.42 & 2.11 & 1.42 \\
\hline $\mathrm{N}$ & 49 & 30 & 49 & 30 & 49 & 30 & 49 & 30 & 49 & 30 \\
\hline $\begin{array}{r}\text { Analysis of } \\
\text { Variance }\end{array}$ & & & & & & & & & & \\
\hline DF (model) & 1 & 1 & 1 & 1 & 1 & 1 & 1 & 1 & 3 & 3 \\
\hline DF (error) & 47 & 28 & 47 & 28 & 47 & 28 & 47 & 28 & 45 & 26 \\
\hline SS (model) & 3.10 & 28.19 & 14.68 & 29.33 & 19.48 & 22.33 & 12.44 & 41.20 & 22.95 & 46.97 \\
\hline SS (error) & 175.58 & 88.54 & 164.00 & 87.40 & 159.20 & 94.40 & 166.24 & 75.54 & 155.73 & 69.76 \\
\hline MS (model) & 3.10 & 28.19 & 14.68 & 29.33 & 19.48 & 22.33 & 12.44 & 41.20 & 7.65 & 15.66 \\
\hline MS (error) & 3.74 & 3.16 & 3.49 & 3.12 & 3.39 & 3.37 & 3.54 & 2.70 & 3.46 & 2.68 \\
\hline F Ratio & 0.83 & 8.92 & 4.21 & 9.40 & 5.75 & 6.62 & 3.52 & 15.27 & 2.21 & 5.84 \\
\hline Prob $>F$ & 0.3672 & $0.0058^{*}$ & $0.0458^{*}$ & $0.0048^{*}$ & $0.0205^{*}$ & $0.0156^{*}$ & 0.0670 & $0.0005^{*}$ & 0.1000 & $0.0035^{*}$ \\
\hline $\begin{array}{l}\text { Parameter } \\
\text { Estimates }\end{array}$ & & & & & & & & & & \\
\hline Intercept & $\begin{array}{c}1.95 \\
5.89 \\
<0.0001^{*}\end{array}$ & $\begin{array}{c}0.76 \\
1.95 \\
0.0618\end{array}$ & $\begin{array}{c}1.87 \\
6.41 \\
<0.0001 *\end{array}$ & $\begin{array}{c}0.90 \\
2.46 \\
0.0201^{*}\end{array}$ & $\begin{array}{c}1.73 \\
5.65 \\
<0.0001^{*}\end{array}$ & $\begin{array}{c}0.87 \\
2.21 \\
0.0358^{*}\end{array}$ & $\begin{array}{c}1.77 \\
5.45 \\
<0.0001^{*}\end{array}$ & $\begin{array}{c}0.91 \\
2.80 \\
0.0091^{*}\end{array}$ & $\begin{array}{c}1.66 \\
5.04 \\
<0.0001^{*}\end{array}$ & $\begin{array}{c}0.68 \\
1.88 \\
0.0707\end{array}$ \\
\hline $\begin{array}{r}\text { Total IP } \\
\text { items }\end{array}$ & $\begin{array}{c}0.003 \\
0.91 \\
0.3672\end{array}$ & $\begin{array}{c}0.012 \\
2.99 \\
0.0058^{*}\end{array}$ & & & & & & & & \\
\hline Patents & & & $\begin{array}{c}0.02 \\
2.05 \\
0.0458^{*}\end{array}$ & $\begin{array}{c}0.04 \\
3.07 \\
0.0048^{*}\end{array}$ & & & & & $\begin{array}{c}0.008 \\
0.73 \\
0.4693\end{array}$ & $\begin{array}{c}0.012 \\
\mathbf{0 . 6 6} \\
0.5121\end{array}$ \\
\hline $\begin{array}{r}\text { Trade } \\
\text { secrets }\end{array}$ & & & & & $\begin{array}{c}0.025 \\
2.40 \\
0.0205^{*}\end{array}$ & $\begin{array}{c}0.028 \\
2.57 \\
0.0156^{*}\end{array}$ & & & $\begin{array}{c}0.017 \\
1.23 \\
0.2251\end{array}$ & $\begin{array}{c}0.012, \\
1.08 \\
0.2902\end{array}$ \\
\hline Trademarks & & & & & & & $\begin{array}{c}0.053 \\
1.88 \\
0.0670\end{array}$ & $\begin{array}{c}0.145 \\
3.91 \\
0.0005^{*}\end{array}$ & $\begin{array}{c}0.014, \\
0.40 \\
0.6901\end{array}$ & $\begin{array}{c}0.103 \\
2.07 \\
0.0484 *\end{array}$ \\
\hline
\end{tabular}

Key to Parameter Estimates: Coefficient of Correlation, $\boldsymbol{t}$ Ratio, Prob $>|t| \quad\left({ }^{*} \mathrm{P}<0.05=\right.$ significance level)

Dependent variable for all models = Financial Performance Index 


\section{K.W. Willoughby}

The results for Model 5 interestingly also show that the use of trademarks, rather than patents or trade secrets, is dispositive for the relative impact of intellectual property on the performance of high R\&D-intensity firms versus low R\&D-intensity firms. This is demonstrated even more starkly by the results of Model 4. In Model 4 it is revealed that there is a probability of 0.0005 that the impact of investment in trademarks on the financial performance of the R\&D-intensive firms is merely a coincidence; while, in contrast, it is revealed that there is no statistically significant relationship between investment in trademarks and the financial performance of those firms with below average levels of activity in research and development.

The results in Table 5 for Model 2 and Model 3 show that -in contrast with the situation we just observed with regards to trademarks - the positive impact of investment in intellectual property on the financial performance of firms may be observed for both patents and trade secrets, in the cases of both low R\&D-intensity firms and high R\&Dintensity firms. In other words, financial advantages will generally accrue to firms from investing in patents and trade secrets regardless of those firms' relative levels of concentration on research and development activities. As shown in Model 2, the statistical significance of the relationship between investment in patents and positive financial performance is stronger for $R \& D$-intensive firms than it is for those firms exhibiting below-average R\&D intensity. Nevertheless, the fact remains that, as a general rule, the technology firms in this study sample benefit financially from investment in patents regardless of what proportion of their activities are devoted to research and development.

In summary, the results summarized in Table 5 show that, overall, the more that a firm concentrates its activities on research and development the more likely it is to benefit financially from investment in intellectual property. Trademarks appear to be especially important for this relationship. Nevertheless, while, in the cases of patents and trade secrets, the statistical significance of the IP-performance relationship appears to be strongest for R\&D-intensive firms, it is also apparent that the firms benefit from investment in both patents and trade secrets regardless of the proportion of their total activity devoted to research and development.

\section{The Moderating Role of Production Activities}

Having investigated the moderating influence of research and development on the relationship between investment in intellectual property by firms and their relative financial performance it may also be instructive to investigate the moderating role of the firms' engagement in "downstream" production activities. In other words, it will be appropriate to explore the degree to which the production intensity of a firm's activities affects the relationship between investment in intellectual property and financial performance. Do firms benefit more, or benefit less, from investment in intellectual property as they engage more heavily in the commercial production of goods or services?

To explore this topic, models 1, 2, 3, 4 and 5 were tested for two different groups of firms in the data set: one group designated as having "low production intensity" and the other designated as having "high production intensity." An estimate of the percentage of total work time devoted to the production of goods or services by all employees combined, over a period of one year, was obtained for each firm. In other words, the proportion of annual full-time-equivalent employment devoted to production functions 
What impact does IP have on the business performance of technology firms?

was identified for each firm in the data set. The mean figure for all firms in the data set was then calculated and each firm was classified according to whether its proportion was higher or lower than average. If the percentage of a firm's total annual work-time devoted

Table 6 Intellectual Property and Financial Performance: Low vs. High Production Intensity

\begin{tabular}{|c|c|c|c|c|c|c|c|c|c|c|}
\hline \multirow[b]{2}{*}{ Variables } & \multicolumn{2}{|c|}{ Model 1} & \multicolumn{2}{|c|}{ Model 2} & \multicolumn{2}{|c|}{ Model 3} & \multicolumn{2}{|c|}{ Model 4} & \multicolumn{2}{|c|}{ Model 5} \\
\hline & 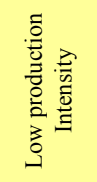 & 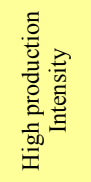 & 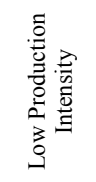 & 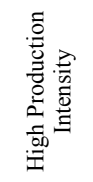 & 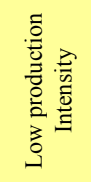 & 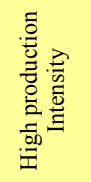 & 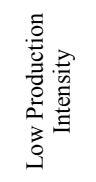 & 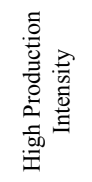 & 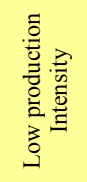 & 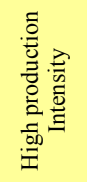 \\
\hline $\mathrm{R}^{2}$ & 0.06 & 0.07 & 0.03 & 0.26 & 0.11 & 0.15 & 0.11 & 0.21 & 0.15 & 0.33 \\
\hline Adj. $R^{2}$ & 0.03 & 0.05 & -0.007 & 0.25 & 0.08 & 0.13 & 0.08 & 0.19 & 0.05 & 0.29 \\
\hline RMS error & 1.80 & 2.02 & 1.84 & 1.80 & 1.76 & 1.93 & 1.75 & 1.87 & 1.78 & 1.75 \\
\hline Mean & 2.01 & 1.74 & 2.01 & 1.74 & 2.01 & 1.74 & 2.01 & 1.74 & 2.01 & 1.74 \\
\hline $\mathrm{N}$ & 31 & 48 & 31 & 48 & 31 & 48 & 31 & 48 & 31 & 48 \\
\hline $\begin{array}{c}\text { Analysis of } \\
\text { Variance }\end{array}$ & & & & & & & & & & \\
\hline DF (model) & 1 & 1 & 1 & 1 & 1 & 1 & 1 & 1 & 3 & 3 \\
\hline DF (error) & 29 & 46 & 29 & 46 & 29 & 46 & 29 & 46 & 27 & 44 \\
\hline SS (model) & 6.47 & 13.96 & 2.63 & 53.05 & 10.66 & 30.80 & 11.33 & 42.35 & 14.69 & 67.24 \\
\hline SS (error) & 93.97 & 188.59 & 97.81 & 149.49 & 89.78 & 171.74 & 89.11 & 160.19 & 85.76 & 135.30 \\
\hline MS (model) & 6.47 & 13.96 & 2.63 & 53.05 & 10.66 & 30.80 & 11.33 & 42.35 & 4.90 & 22.41 \\
\hline MS (error) & 3.24 & 4.10 & 3.37 & 3.25 & 3.10 & 3.73 & 3.07 & 3.48 & 3.18 & 3.08 \\
\hline F Ratio & 2.00 & 3.40 & 0.78 & 16.33 & 3.44 & 8.25 & 3.69 & 12.16 & 1.54 & 7.29 \\
\hline Prob $>F$ & 0.1684 & 0.0714 & 0.3841 & $0.0002 *$ & 0.0737 & $0.0061^{*}$ & 0.0647 & $0.0011^{*}$ & 0.2266 & $0.0005^{*}$ \\
\hline $\begin{array}{c}\text { Parameter } \\
\text { Estimates }\end{array}$ & & & & & & & & & & \\
\hline Intercept & $\begin{array}{c}1.70 \\
4.37 \\
<0.0001^{*}\end{array}$ & $\begin{array}{c}1.39 \\
3.99 \\
0.0002^{*}\end{array}$ & $\begin{array}{c}1.88 \\
\mathbf{5 . 2 1} \\
<0.0001^{*}\end{array}$ & $\begin{array}{c}1.23 \\
4.24 \\
0.0001^{*}\end{array}$ & $\begin{array}{c}1.63 \\
4.32 \\
0.0002 *\end{array}$ & $\begin{array}{c}1.26 \\
3.88 \\
0.0003^{*}\end{array}$ & $\begin{array}{c}1.73 \\
4.95 \\
<0.0001^{*}\end{array}$ & $\begin{array}{c}1.09 \\
3.35 \\
0.0016^{*}\end{array}$ & $\begin{array}{c}1.62 \\
4.19 \\
0.0003^{*}\end{array}$ & $\begin{array}{c}0.90 \\
2.79 \\
0.0077^{*}\end{array}$ \\
\hline $\begin{array}{r}\text { Total IP } \\
\text { items }\end{array}$ & $\begin{array}{c}0.005, \\
1.41 \\
0.1684\end{array}$ & $\begin{array}{c}0.006 \\
1.85 \\
0.0714\end{array}$ & & & & & & & & \\
\hline Patents & & & $\begin{array}{c}0.009 \\
\boldsymbol{0 . 8 8} \\
0.3841\end{array}$ & $\begin{array}{c}0.04 \\
4.04 \\
0.0002 *\end{array}$ & & & & & $\begin{array}{c}0.006,- \\
0.53 \\
0.6022\end{array}$ & $\begin{array}{c}0.028 \\
2.08 \\
0.0436^{*}\end{array}$ \\
\hline $\begin{array}{r}\text { Trade } \\
\text { secrets }\end{array}$ & & & & & $\begin{array}{c}0.018 \\
1.86 \\
0.0737\end{array}$ & $\begin{array}{c}0.035 \\
2.87 \\
0.0061^{*}\end{array}$ & & & $\begin{array}{c}0.012 \\
0.95 \\
0.3504\end{array}$ & $\begin{array}{c}0.012 \\
\boldsymbol{0 . 8 9} \\
0.0379 *\end{array}$ \\
\hline Trademarks & & & & & & & $\begin{array}{c}0.057 \\
1.92 \\
0.0647\end{array}$ & $\begin{array}{c}0.117 \\
3.49 \\
0.0011^{*}\end{array}$ & $\begin{array}{c}0.049 \\
1.13 \\
0.2704\end{array}$ & $\begin{array}{c}0.065, \\
1.80 \\
0.0795\end{array}$ \\
\hline
\end{tabular}

Key to Parameter Estimates: Coefficient of Correlation, $\boldsymbol{t}$ Ratio, Prob $>|t| \quad\left({ }^{*} \mathrm{P}<0.05=\right.$ significance level $)$

Dependent variable for all models $=$ Financial Performance Index

to production was less than average it was classified as exhibiting "low production intensity" and, conversely, if the percentage of a firm's total annual work-time devoted to production was greater than average it was classified as exhibiting "high production intensity." Separate regression calculations were then carried out for each of the two 


\section{K.W. Willoughby}

groups of firms for each of the five models. The results of this exercise are summarized in Table 6. When interpreting the statistics in Table 6 it is important to recognize that the percentage of a firm's total work time devoted to production activities is not, by definition, the inverse of the percentage of that firm's total work time devoted to research and development. Firms also devote time and money to other activities, such as management, marketing, long-range planning, public relations, government affairs, community service, and other functions and services not directly related to either R\&D or production. As shown in Table 3, there is a correlation coefficient of about -0.6 between R\&D intensity and production intensity for the firms in our data set. This means that there is a general tendency for firms to reduce the proportion of their total time devoted to R\&D as they move downstream towards greater emphasis on the commercial production of goods and services. However, just because that is the general trend it does not follow that technology firms are automatically forced in to making a trade-off between either R\&D or production. Individual firms do not necessarily conform to the general pattern: a minority of firms may in fact be simultaneously R\&D intensive and production intensive. Hence, there is value in conducting an analysis of the moderating influence of engagement in production activities (over and above our analysis of the moderating influence of $R \& D$ intensity) on the relationship between investment in intellectual property by firms and their financial performance.

Overall, the results in Table 6 show that - when the models include only patents, trade secrets or trademarks (i.e., when copyright protected items and technology licenses are excluded from the models) - the degree to which firms devote time to production activities does indeed make a difference to the overall impact on their financial performance of their investment in intellectual property. In Models 2, 3, 4 and 5 the positive impact on financial performance of investment in intellectual property is strong for the high production intensity firms; and in all cases the relationship is statistically significant. This pattern holds true for all three of the dominant types of intellectual property held by the firms (patents, trade secrets and trademarks) but it is especially robust in the case of patents. The statistical results for Model 2 in Table 6 show that there is a probability of only 0.0002 that the positive relationship between levels of patent ownership and financial performance for the high production intensity firms may be explained by chance; and for the low production intensity firms there is no statistically significant relationship between levels of patent ownership and financial performance. The results for Models 3 and 4 show that a similar pattern may be observed for the cases of both trade secrets and trademarks, in their own right, as discrete factors. For Model 5, which includes patents, trade secrets and trademarks in the equation, there is a probability of only 0.0005 that the positive relationship may be explained by chance. Only in the case of Model 1-where all types of intellectual property in addition to patents, trade secrets and trademarks are included in the data-is the relationship between intellectual property and financial performance not statistically significant for the high production intensity firms. In short, the results in Table 6 demonstrate that, as a general rule, the more that technology firms engage in the commercial production of goods and services the greater is the financial benefit that they may obtain from possessing a strong intellectual property portfolio.

In summary, the statistical results portrayed in Tables 5 and 6 indicate that a positive relationship between the size of a firm's intellectual property portfolio and its financial performance may be enjoyed by both R\&D-intensive firms and production-intensive 
What impact does IP have on the business performance of technology firms?

firms. For production intensive firms, patents, trade secrets and trademarks in particular are significant.

\section{Conclusions and Discussion}

A summary of the overall results of the preceding statistical analysis is presented in Table 7. The first conclusion that may be drawn from Table 7 is that Hypothesis 1 should be accepted. ${ }^{3}$ In other words, there is statistically significant support for the proposition that the accumulation of intellectual property by technology firms has a positive impact on their financial performance. This broad conclusion applies generally across all types of firms in the sample and to intellectual property "in general." However, the results in Table 7 also reveal that the nature of the relationship is not uniform across the various types of intellectual property. The positive contributions of intellectual property to financial performance arise predominantly from the firms' investments in patents, trade secrets and trademarks, rather than from their investment in copyright-protected items or from obtaining licenses to use technology from external sources.

The second conclusion that may be drawn from Table 7 is that Hypothesis 2 should be accepted. In other words, there is statistically significant support for the proposition that, insofar as the accumulation of intellectual property by technology firms has a positive impact on their financial performance, the degree of this positive impact will be positively related to the degree to which the firms concentrate their efforts on research and development activities. In short, from the point of view of financial performance, intellectual property appears to matter more for R\&D-intensive firms than it does for firms that place less emphasis on research and development. However, this conclusion needs to be qualified. The positive moderating effect of R\&D-intensity on the contribution to the financial performance of firms by intellectual property is accounted for mostly by trademarks. In contrast to the situation with trademarks, it appears that the financial performance of firms may be enhanced through investment in either patents or trade secrets regardless of how much emphasis they place on research and development. However, notwithstanding these facts (and as was also noted earlier in this paper, in discussion of Table 5), it does appear that the more R\&D-intensive a firm becomes, the stronger and more significant the relationship becomes between its investment in both patents and trade secrets and its financial performance. Even though trademarks are clearly the most important type of intellectual property vis-à-vis Hypothesis 2, patents and trade secrets also play a role. Thus, with appropriate qualifications, Hypothesis 2 may be affirmed and accepted.

The third conclusion that may be drawn from Table 7 is that Hypothesis 3 should be accepted. In other words, there is statistically significant support for the proposition that, insofar as the accumulation of intellectual property by technology firms has a positive impact on their financial performance, the degree of this positive impact will be

\footnotetext{
${ }^{3}$ Strictly speaking, the formally correct way of expressing this would be to say that there is sufficient statistical evidence to reject the null hypothesis for Hypothesis 1 . However, for the sake of convenience and simplicity of expression, the result is expressed here in a positive form: that there is sufficient statistical evidence to accept the hypothesis (with a high degree of confidence that the results could not be explained by chance).
} 


\section{K.W. Willoughby}

positively related to the degree to which the firms concentrate their efforts on the commercial production of goods or services. In short, from the point of view of financial performance, intellectual property appears to matter more for production-intensive firms than it does for firms that place less emphasis on production activities. This conclusion is equally valid for patents, trade secrets and trademarks. Nevertheless, this conclusion needs to be qualified in one respect. The aggregate positive effect of production-intensity on the relationship between intellectual property and the financial performance of bioscience-technology firms is diluted by the inclusion of copyright and licenses in the calculations. The positive moderating effect of production intensity may only be observed for patents, trade secrets and trademarks. Thus, with this qualification, Hypothesis 3 may also be affirmed and accepted. It is perhaps also worth noting that the statistical significance of this positive relationship is the greatest for patents. In other words, patents appear to play the most significant role in improving the financial performance of technology firms as they move "downstream" to emphasize the commercial production of goods or services.

Table 7 Relationship Between Accumulation of Intellectual Property and Financial Performance

\begin{tabular}{|c|c|c|c|c|c|}
\hline \multirow[b]{2}{*}{$\begin{array}{c}\text { Type of } \\
\text { Intellectual Property }\end{array}$} & \multicolumn{5}{|c|}{ Category of Technology Firms in the Study Sample } \\
\hline & $\begin{array}{c}\text { All Firms } \\
\text { (whole data set) }\end{array}$ & $\begin{array}{c}\text { Firms with } \\
\text { Low R\&D } \\
\text { Intensity }\end{array}$ & $\begin{array}{c}\text { Firms with } \\
\text { High R\&D } \\
\text { Intensity }\end{array}$ & $\begin{array}{l}\text { Firms with } \\
\text { Low } \\
\text { Production } \\
\text { Intensity }\end{array}$ & $\begin{array}{c}\text { Firms with } \\
\text { High } \\
\text { Production } \\
\text { Intensity }\end{array}$ \\
\hline Patents & $\begin{array}{l}\text { Positive, } \\
\text { highly } \\
\text { significant }\end{array}$ & $\begin{array}{l}\text { Positive, } \\
\text { significant }\end{array}$ & $\begin{array}{l}\text { Positive, } \\
\text { highly } \\
\text { significant }\end{array}$ & $\begin{array}{c}\text { Neutral / } \\
\text { insignificant }\end{array}$ & $\begin{array}{c}\text { Positive, } \\
\text { very highly } \\
\text { significant }\end{array}$ \\
\hline Trade secrets & $\begin{array}{l}\text { Positive, } \\
\text { highly } \\
\text { significant }\end{array}$ & $\begin{array}{l}\text { Positive, } \\
\text { significant }\end{array}$ & $\begin{array}{c}\text { Positive, } \\
\text { more significant }\end{array}$ & $\begin{array}{c}\text { Neutral / } \\
\text { insignificant }\end{array}$ & $\begin{array}{l}\text { Positive, } \\
\text { highly } \\
\text { significant }\end{array}$ \\
\hline Trademarks & $\begin{array}{l}\text { Positive, } \\
\text { very highly } \\
\text { significant }\end{array}$ & $\begin{array}{c}\text { Neutral / } \\
\text { insignificant }\end{array}$ & $\begin{array}{l}\text { Positive, } \\
\text { very highly } \\
\text { significant }\end{array}$ & $\begin{array}{c}\text { Neutral / } \\
\text { insignificant }\end{array}$ & $\begin{array}{l}\text { Positive, } \\
\text { highly } \\
\text { significant }\end{array}$ \\
\hline Copyright protected items & $\begin{array}{c}\text { Neutral / } \\
\text { insignificant }\end{array}$ & - & - & - & - \\
\hline Licenses & $\begin{array}{c}\text { Neutral / } \\
\text { insignificant }\end{array}$ & - & - & - & - \\
\hline All types of IP (aggregated) & $\begin{array}{l}\text { Positive, } \\
\text { significant }\end{array}$ & $\begin{array}{c}\text { Neutral / } \\
\text { insignificant }\end{array}$ & $\begin{array}{l}\text { Positive, } \\
\text { highly } \\
\text { significant }\end{array}$ & $\begin{array}{c}\text { Neutral / } \\
\text { insignificant }\end{array}$ & $\begin{array}{l}\text { Positive, } \\
\text { very highly } \\
\text { significant }\end{array}$ \\
\hline
\end{tabular}

The second and third conclusions together provide a simple answer to a question posed at the beginning of this paper: does the strategic orientation of a technology firmspecifically, the intensity of its engagement in either research and development or the production of goods or services - make any difference to the level and character of the impact of intellectual property on its business performance? The answer is yes.

The fourth conclusion that may be drawn from Table 7 was foreshadowed earlier in the paper: the positive stimulus to financial performance from investment in intellectual property may be enjoyed by a bioscience-technology firm regardless of whether its 
primary strategic orientation is towards research and development or towards the commercial production of goods or services.

The results of the research presented in this paper evoke some principles that may be applicable to managers of technology firms, especially managers of firms in the bioscience-technology industries. First, strategies to improve the business performance of a firm will generally require more than simply investing more heavily in R\&D or engaging more heavily in commercial production. It appears necessary for a firm to simultaneously invest in building up an appropriate intellectual property portfolio for it to reap the financial rewards of building up R\&D or production. Second, it is important for managers to artfully employ the right mix of intellectual property rights in support of their technology strategy and business strategy. While patents clearly have a central role to play in the business of technology firms, other types of intellectual property such as trade secrets or trademarks are clearly also important. The strategic management of intellectual property involves not only deciding how much intellectual property protection to assemble in a firm, but also what type of intellectual property rights are appropriate for the technologies, products and markets of the firm, at any one point in time, together with the appropriate geographical domains in which to assert those rights. Third, while the cost of obtaining, maintaining and enforcing intellectual property rights can be very high - especially for small, entrepreneurial firms, including start-ups - the research presented here suggests that, on the whole, it is a price worth paying. The challenge for managers is working out how to strategically manage intellectual property so that the cost of doing so is easily covered by revenue generated through the artful deployment of those IP assets. Associated with that challenge is the challenge of managing intellectual property to enhance the terms upon which investment capital is attracted to the enterprise during the early developmental phases of its business.

The results reported in this paper also have implications for further academic research. To begin with, it is worth noting that the empirical results presented here accord with the dominant view that has begun to emerge in the literature, which is that there is a positive relationship between the size of the intellectual property portfolio owned by firms and their financial performance. However, the challenge of reconciling this view with the results of the minority of studies that appears to have reached the opposite view still remains. The literature provides some clues as to how this might be done. Most of the studies reported earlier in this paper point to variations in industry, technology, geography or environment as explanations for variations in the degree to which intellectual property may legitimately be cited as a determinant of financial performance. Future academic research on the intellectual-property / financial-performance relationship ought to examine more closely the exact manner in which these factors come in to play.

The results presented in this paper are based on data collected from firms in one particular industry context, that of the bioscience-technology industries. By definition, bioscience-technology firms are technology-intensive organizations. This no doubt presents unique considerations. Future research should bear that in mind by applying the approach adopted here to other industries.

Additionally, note should be made of the fact that there are multiple ways of measuring business performance, and of measuring financial performance in particular. Data suitable for calculating some of the more popular measures found in the business literature - such as return-on-assets, operational profitability, or changes in the value of publicly-traded shares - are typically only readily obtainable for publicly listed firms. 


\section{K.W. Willoughby}

This is one reason why most academic studies on business performance are based on data obtained from the public stock markets. Given that only a minority of technology firms are publicly listed, and given that publicly listed firms differ markedly from privately held firms, it is doubtful whether research based on data from publicly traded firms will produce results that properly represent technology based industries as a whole. Likewise, it is difficult to produce robust and widely applicable results for research on technology industries by relying upon the popular measures of financial performance, such as profitability or the market value of publicly traded stocks. For these reasons, and others, the financial performance measure employed in this study was based on weighted revenue-growth data, which are more readily available for both privately held and publicly traded firms, and well as for not-for-profit enterprises engaged in trade. One of the likely explanations for differences in the general conclusions reached by the minority of studies and the majority of studies in the field of intellectual property and financial performance no doubt lies with the contrasting performance measures employed in each project. Future research in this field should perhaps pay more attention to the choice of performance measure and to comparing the differences in results according to which measures are employed.

It is also important to remember that intellectual property is only one of many sets of factors that determine the relative financial performance of firms. The traditional factors that have typically occupied the attention of business researchers - such as leadership, operations, market conditions, the economic environment, financial management, the cost of capital, the cost of resources, the level of human capabilities or social capital in a community, the nature of competitive forces, the level of available technology, the legal environment, the pre-existing competencies of the firm, or organizational dynamics, to name just some of the critical ones-are still extremely important, no matter how sophisticated a firm may be in its intellectual property strategy. Intellectual property is just one additional set of factors to add to the mix. However, the research presented here has demonstrated that intellectual property matters. It needs to be treated, and managed strategically, as a critical function of the modern business enterprise, alongside orthodox functions such as finance, accounting, operations, human resources, marketing, sales, $\mathrm{R} \& \mathrm{D}$, legal affairs or public relations.

Intellectual property, if managed effectively, can make a critical difference to the financial performance of enterprises.

\section{References}

Anuar, H., et al. (2012) 'The role of internal R\&D in operational performance as moderated by intellectual property rights: The Malaysian manufacturing perspective', Journal of Innovation and Business Best Practices, 2012 (Article ID 983677), pp. 1-15.

Arora, A. and Nandkumar, A. (2012) 'Insecure advantage? Markets for technology and the value of resources for entrepreneurial ventures', Strategic Management Journal, Vol. 33, No. 3, pp. 231-251.

Artz, K. W., et al. (2010) 'A longitudinal study of the impact of R\&D, patents, and product innovation on firm performance', Journal of Product Innovation Management, Vol. 27, No. 5, pp. 725-740.

Bessler, W. and Bittelmeyer, C. (2008) 'Patents and the performance of technology firms: Evidence from initial public offerings in Germany', Financial Markets and Portfolio Management, Vol. 22, No. 4, pp. 323-356 
What impact does IP have on the business performance of technology firms?

Bessen, J. (2008) 'The value of U.S. patents by owner and patent characteristics', Research Policy, Vol. 37, No. 5, pp. 932-945.

Blind, K., et al. (2009) 'The influence of strategic patenting on companies' patent portfolios. Research Policy', Vol. 38, No. 2, pp. 428-436.

Blind, K., et al. (2006) 'Motives to patent: Empirical evidence from Germany', Research Policy, Vol. 35 , No. 5, pp. 655-672.

Bollen, L., et al. (2005) 'Linking intellectual capital and intellectual property to company performance', Management Decision, Vol. 43, No. 9, pp. 1161-1185.

Bosworth, D. and Rogers, M. (2001) 'Market value, R\&D and intellectual property: an empirical analysis of large Australian firms', The Economic Record, Vol. 77, No. 239, pp. 323-337.

Cincera, M. (1997) 'Patents, R\&D, and technological spillovers at the firm level: some evidence from econometric count models for patent data', Journal of Applied Econometrics, Vol. 12, No. 3, pp. 265-280.

Cockburn, I. M. and Griliches, Z. (1988) 'Industry effects and appropriability measures in the stock market's valuation of R\&D and patents', American Economic Review, Vol. 78, No. 2, pp. 419423.

Cockburn, I. M., et al. (2010) 'Patent thickets, licensing and innovative performance', Industrial \& Corporate Change, Vol. 19, No. 3, pp. 899-925.

Cohen, S. and Kaimenakis, N. (2007) 'Intellectual capital and corporate performance in knowledge-intensive SMEs', The Learning Organization, Vol. 14, No. 3, pp. 241-262.

Cohen, W. M., et al. (2000) Protecting their intellectual assets: Appropriability conditions and why U.S. manufacturing firms patent (or not) (Working Paper No. 7552), Cambridge, MA, The National Bureau of Economic Research.

Cohen, W. M., et al (2002) 'R\&D spillovers, patents and the incentives to innovate in Japan and the United States', Research Policy, Vol. 31, No. 8-9, pp. 1349-1367.

Elmslie, M. and Portman, S. (2006) Intellectual property: The lifeblood of your company, Chandos, Oxford.

Fitzpatrick, W. M. and DeLullo, S. A. (2005) 'Strategic alliances and the management of intellectual properties: The art of the contract', S.A.M. Advanced Management Journal, Summer, pp. 38-45.

Graham, S. H., et al. (2009) 'High technology entrepreneurs and the patent system: Results of the 2008 Berkeley patent survey', Berkeley Technology Law Journal, Vol. 24, No. 4, pp. 12551327.

Graham, S. J. H. and Sichelman, T. (2008) 'Why do start-ups patent?' Berkeley Technology Law Journal, Vol. 23, No. 3, pp. 1063-1097.

Greenhalgh, C. and Longland, M. (2005) 'Running to stand still? - The value of R\&D, patents and trade marks in innovating manufacturing firms' International Journal of the Economics of Business, Vol. 12, No. 3, pp. 307-328.

Greenhalgh, C. and Rogers, M. (2006) 'The value of innovation: The interaction of competition, R\&D and IP', Research Policy, Vol. 35, No. 4, pp. 562-580.

Greenhalgh, C. and Rogers, M. (2007) 'The value of intellectual property rights to firms and society', Oxford Review of Economic Policy, Vol. 23, No. 4, pp. 541-567.

Greenhalgh, C., et al. (1996) 'Intellectual property, technological advantage and trade performance of UK manufacturing industries', Applied Economics, Vol. 28, No. 5, pp. 509-519.

Griliches, Z. (1981) 'Market value, R\&D, and patents', Economic Letters, Vol. 7, pp. 183-187.

Hanel, P. (2008) 'The use of intellectual property rights by manufacturing firms in Canada', Economics of Innovation and New Technology, Vol. 17, No. 4, pp. 285-309.

Hsu, D. H. and Ziedonis, R. H. (2013) 'Resources as dual sources of advantage: Implications for valuing entrepreneurial-firm patents', Strategic Management Journal, Vol. 34, No. 7, pp. 761781. 


\section{K.W. Willoughby}

Juma, N. and McGee, J. (2006) 'The relationship between intellectual capital and new venture performance: An empirical investigation of the moderating role of the environment', International Journal of Innovation and Technology Management, Vol. 3, No. 4, 379-405.

Lehman, B. (1996) 'Intellectual property: America's competitive advantage in the 21 st century', Columbia Journal of World Business, Vol. 6, No. 15, pp. 6-18.

Lichtenthaler, U. (2009) 'The role of corporate technology strategy and patent portfolios in low-, medium- and high-technology firms', Research Policy, Vol. 38, No. 3, pp. 559-569.

Lichtenthaler, U. and Ernst, H. (2012) 'Integrated knowledge exploitation: The complementarity of product development and technology licensing', Strategic Management Journal, Vol. 33, No. 5, pp. 513-534.

Lynskey, M. J. (2009) 'Aligning strategy and intellectual property to maximise business value: A proposal for new technology-based firms', International Journal of Intellectual Property Management, Vol. 3, No. 4, pp. 301-325.

Mahlich, J. C. (2010) 'Patents and performance in the Japanese pharmaceutical industry: An institution-based view', Asia Pacific Journal of Management, Vol. 27, No. 1, pp. 99-113.

Mann, R. J. (2005) 'Do patents facilitate financing in the software industry? Texas Law Review, Vol. 83, No. 4, pp. 961-1030.

Mann, R. J. and Sager, T. W. (2007) 'Patents, venture capital, and software start-ups', Research Policy, Vol. 36, No. 2, pp. 193-208.

Martin, N. L. and Mykytyn, P. P. (2009) 'Evaluating the financial performance of business method patent owners', Information Systems Management, Vol. 26, No. 3, pp. 285-301.

Mulotte, L., et al. (2013) 'Does pre-entry licensing undermine the performance of subsequent independent activities? Evidence from the global aerospace industry, 1944-2000', Strategic Management Journal, Vol. 34, No. 3, pp. 358-372.

Namvar, M., et al. (2010) 'Exploring the impacts of intellectual property on intellectual capital and company performance: The case of Iranian computer and electronic organizations', Management Decision, Vol. 48, No. 5, pp. 676-697.

Pandit, S., et al. (2011) 'The effect of research and development (R\&D) inputs and outputs on the relation between the uncertainty of future operating performance and R\&D expenditures', Journal of Accounting, Auditing and Finance, Vol. 26, No. 1, pp. 121-144.

Pacheco-de-Almeida, G. and Zemsky, P. B. (2012) 'Some like it free: Innovators' Strategic use of Disclosure to slow down Competition', Strategic Management Journal, Vol. 33, No. 7, pp. 773-793.

Parchomovsky, G. and Wagner, R. P. (2005) 'Patent portfolios', University of Pennsylvania Law Review, Vol. 154, No. 1, pp. 1-77.

Peeters, C. and van Pottelsberghe de la Potterie, B. (Eds.), (2006) Economic and management perspectives on intellectual property rights, Palgrave Macmillan, Basingstoke \& New York.

Pisano, G. P. and Teece, D. J. (2007) 'How to capture value from innovation: Shaping intellectual property and industry architecture', California Management Review, Vol. 50, No. 1, pp. 278296.

Rherrad, I. and Gallaud, D. (2009) 'Exploring appropriation strategies: Evidence from French hightech firms', International Journal of Technology Transfer and Commercialization, Vol. 8, No. 4, pp. 316-339.

Rose, C., et al. (2007) 'Communicating the value of your intellectual property to Wall Street: A properly-constructed IP story can benefit a company and its stockholders', Research Technology Management, March-April, pp. 36-40.

Roy, D. (2013) Intellectual property strategy for competitive advantage', International Journal of Intellectual Property Management, Vol. 6, No. 1/2, pp. 36-61.

Suh, D. and Hwang, J. (2010) 'An analysis of the effect of software intellectual property rights on the performance of software firms in South Korea', Technovation, Vol. 30, No. 5/6, pp. 376385 . 
What impact does IP have on the business performance of technology firms?

Tabachnick, B. G. and Fidell, L. S. (1989) Using multivariate statistics, 2nd ed., Harper \& Row, New York.

Valentini, G. (2012) 'Measuring the effect of M\&A on patenting quantity and quality', Strategic Management Journal, Vol. 33, No. 3, pp. 336-346.

Walden, E. A. (2005) 'Intellectual property rights and cannibalization in information technology outsourcing contracts', MIS Quarterly, Vol. 29, No. 4, pp. 699-720.

Willoughby, K. W. (2004) 'The Affordable Resources strategy and the Milieux Embeddedness strategy as alternative approaches to facilitating innovation in a knowledge-intensive industry', The Journal of High Technology Management Research, Vol. 15, No. 1, pp. 91-121.

Willoughby, K. W. (2008) 'How do entrepreneurial technology firms really get financed, and what difference does it make?' International Journal of Innovation and Technology Management, Vol. 5, No. 1, pp. 1-28.

Willoughby, K. W. (2013) 'Intellectual property management and technological entrepreneurship', International Journal of Innovation and Technology Management, Vol. 10, No. 6 (in press). 